\title{
Energy Conservation Opportunities in Pulp \& Paper Industry
}

\author{
Ashok Kumar Pandey, Ravi Prakash* \\ Department of Mechanical Engineering, Motilal Nehru National Institute of Technology, Allahabad (UP), India \\ Email: akpandeygp@gmail.com, *rprakash234@gmail.com
}

How to cite this paper: Pandey, A.K. and Prakash, R. (2018) Energy Conservation Opportunities in Pulp \& Paper Industry. Open Journal of Energy Efficiency, 7, 89-99. https://doi.org/10.4236/ojee.2018.74006

Received: October 8, 2018

Accepted: December 2, 2018

Published: December 5, 2018

Copyright $\odot 2018$ by authors and Scientific Research Publishing Inc. This work is licensed under the Creative Commons Attribution International License (CC BY 4.0).

http://creativecommons.org/licenses/by/4.0/

\begin{abstract}
Industrial sector is the largest user of energy in India and in many parts of the world. The pulp and paper industry accounted for $6 \%$ of total global industrial energy consumption, being the fourth largest energy consumer worldwide. For India, energy audit of a paper carton manufacturing unit was earlier reported with the following results. The specific electrical and thermal energy consumption was estimated as $91.85 \mathrm{kWh} /$ ton and $1619 \mathrm{MJ} /$ ton paper respectively. Annual energy saving potential was found to be $5.9 \%$ of the total annual energy consumption. With a view to identifying energy conservation and $\mathrm{CO}_{2}$ mitigation opportunities in writing, tissue, and craft paper production, this article presents energy auditing of a paper industry (Orient Paper Mills) in Amlai, Shahdol, Madhya Pradesh, India. The specific energy consumption of the typical paper industry in India was evaluated as $34.3 \mathrm{GJ}$ per ton paper and specific $\mathrm{CO}_{2}$ emissions as 3.4 tons $\mathrm{CO}_{2}$ per ton paper. Some energy conservation opportunities for this industry were identified with significant energy saving (nearly 3.5\%) and money saving potential with payback periods not exceeding 2 years in general.
\end{abstract}

\section{Keywords}

Energy Benchmarking, Pulp \& Paper Industry, Energy Conservation, Carbon Emissions

\section{Introduction}

The industrial sector is the largest user of energy in India and in many parts of the world. The pulp and paper industry was responsible for about $6 \%$ of the world total industrial energy consumption, being the fourth largest industrial energy user worldwide [1]. Several energy auditing studies have been reported for pulp and paper industry recently. For Netherlands, the average specific 
energy consumption (SEC) of tissue paper production was the highest i.e. 14.7 GJ/ton paper. However, it was less for graph and board sheets [1].

For China, average primary energy intensity for paper production was reported as $11 \mathrm{GJ} /$ ton paper and $\mathrm{CO}_{2}$ intensity as 1.04 tons $\mathrm{CO}_{2}$ per ton paper [2]. However, energy use in pulping was not included in this study. For India, energy audit of a paper carton manufacturing unit has been reported [3] with the following results. The specific electrical and thermal energy consumption was estimated and found to be $91.85 \mathrm{kWh} /$ ton and $1619 \mathrm{MJ} /$ ton paper. Annual energy saving potential was found to be $5.9 \%$ of the total annual energy consumption [3].

For energy security and sustainability in Japan, Barai \& Saha [4] examined the role of renewable energy along with cascaded use of waste heat in energy intensive industries. Further, Moroga et al. [5] surveyed the energy and environmental policies adopted by various regions in Japan highlighting the importance of solar power generation as well as energy saving projects for realizing a sustainable society. An industrial case study by Zahara [6] focuses on the application of sustainability in the sugar industry in Indonesia. The utilization of waste and side products of sugar production (i.e. sugarcane bagasse and molasses) was found to be economically attractive for producing various chemicals such as bioethanol and lactic acid etc. This study highlights the importance of value addition in process industries by waste utilization.

For Indian chemical industry, the need for carbon footprint labeling was recommended by Sharma [7] using lifecycle assessment of industrial energy consumption in order to address global warming challenge. A study on energy conservation in textile industry was reported by Dhayaneswaran and Ashokkumar [8] indicating significant energy saving potential by optimization of motors and process parameters. Similarly, Madlool et al. [9] provided a critical review on energy use in cement industry with recommendations for energy saving through improvements in grinding process and waste heat recovery.

To estimate energy use and carbon emissions from writing, tissue and craft paper production in India, the energy auditing of a typical paper industry (Orient Paper Mills) located at Amlai, Shahdol, Madhya Pradesh, India has been presented in this paper. Energy saving opportunities for this industry have also been identified through this study.

\section{Methodology}

The paper production plant i.e. the Orient Paper Mills, taken as a case study as mentioned above, has three major outputs: writing paper, tissue paper and craft paper. The raw-material input to the plant is bamboo and eucalyptus chips obtained from nearby forest. The electrical and thermal energy demands of the plant are met through a coal-fired Combined Heat \& Power (CHP) system with pass-out condensing turbines of $77 \mathrm{MW}$ capacities. Four steam turbines of 30 MW, $25 \mathrm{MW}, 16 \mathrm{MW}$, and $6 \mathrm{MW}$ capacities are being used. The steam condi- 
tions at turbine inlet are $60 \mathrm{bar}, 440^{\circ} \mathrm{C}$. For heating requirements, the steam is bled from the turbines at 10 bar and $167^{\circ} \mathrm{C}$. About $33 \%$ of the electricity and about $37 \%$ of steam by mass (at 20 bar, $220^{\circ} \mathrm{C}$ ) generated from the CHP system is exported to the adjacent chemical factory.

The pulp \& paper industry energy auditing process is used to establish the overall energy consumption in the industry, estimate the scope for saving, identify the easiest areas for attention, identify immediate improvements and savings, set a reference point, identify areas for more detailed study and measurements. Such an industrial energy audit will help to keep focus on variations which occur in the energy costs, availability and reliability of supply of energy, decide on appropriate energy mix, identify energy conservation technologies, retrofit for energy conservation equipment etc.

Figure 1 provides the energy flow diagram of the paper production plant with four paper machines i.e. PM1 (writing paper); PM2 \& PM3 (tissue paper); and PM4 (craft paper) including the wood chipper \& pulp mill.

The Specific Energy Consumption (SEC) and Specific Carbon Emission (SCE) of the plant may be evaluated from the following expressions:

1) Specific Energy Consumption (SEC) [2]:

$$
\mathrm{SEC}_{p m}=\frac{\text { Annual Primary Energy Consumption }_{(p m)}(\mathrm{MJ} \text { or GJ })}{\text { Annual Production }_{(p m)}(\text { tonne paper })}
$$

here, the suffix "pm" refers to a particular paper machine.

2) Specific $\mathrm{CO}_{2}$ Emissions (SCE) [2]:

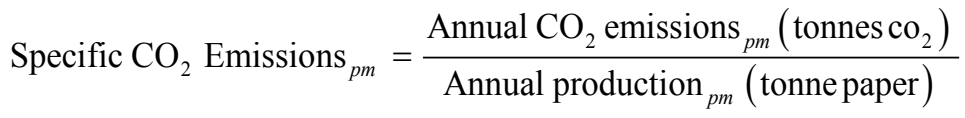

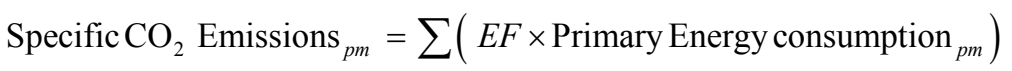

here EF refers to the carbon emission factor of the energy consumed. The $\mathrm{CO}_{2}$ emission factor for coal as reported from the plant is 1.65 tons $\mathrm{CO}_{2}$ /ton of coal; the carbon content of coal being $45 \%$ with its calorific value as $4000 \mathrm{k} \mathrm{Cal} / \mathrm{kg}$ (i.e. 16.7 MJ/kg).

The energy and process flow diagrams of the plant are shown in Figure 1 and Figure 2 respectively. A photograph of the plant is also shown in Figure 3.

\section{Data Collection and Analysis}

The overall paper production and energy use data obtained from the plant are presented in Table 1 and Table 2 respectively. The specific energy consumption (SEC) and specific $\mathrm{CO}_{2}$ emissions (SCE) of paper from quarterly production data is presented in Table 3. From Table 3, the average SEC of the plant is evaluated as $34.3 \mathrm{GJ} /$ ton paper with an average SCE as 3.4 tons $\mathrm{CO}_{2}$ /ton paper. Almost the entire energy consumption of the plant is in the form of coal. The use of furnace oil is only marginal, as it is only used for lighting of the boiler furnace. Hence furnace oil energy has been neglected in the energy audit. 
The following data as obtained from the plant was used in the calculations:

For production of $1 \mathrm{kWh}_{\mathrm{e}}$ power, $0.645 \mathrm{~kg}$ of coal was consumed with $\mathrm{CV}$ of $16.7 \mathrm{MJ} / \mathrm{kg}$.

For production of 1 ton of steam, coal consumption was recorded as $0.196 \mathrm{~kg}$ with thermal energy equivalent as $3.27 \mathrm{MJ}$.

1 ton coal produced 1.65 tons of $\mathrm{CO}_{2}$.

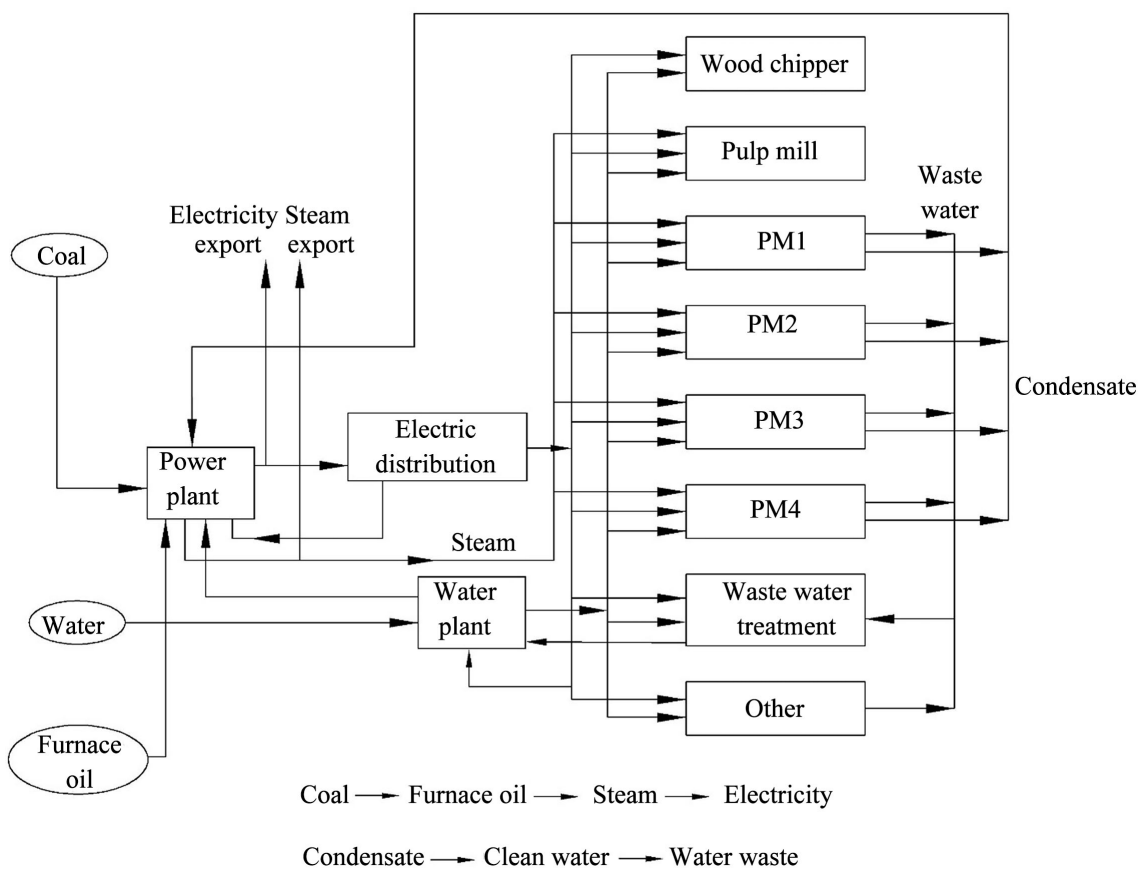

Figure 1. Energy flow diagram of paper production.

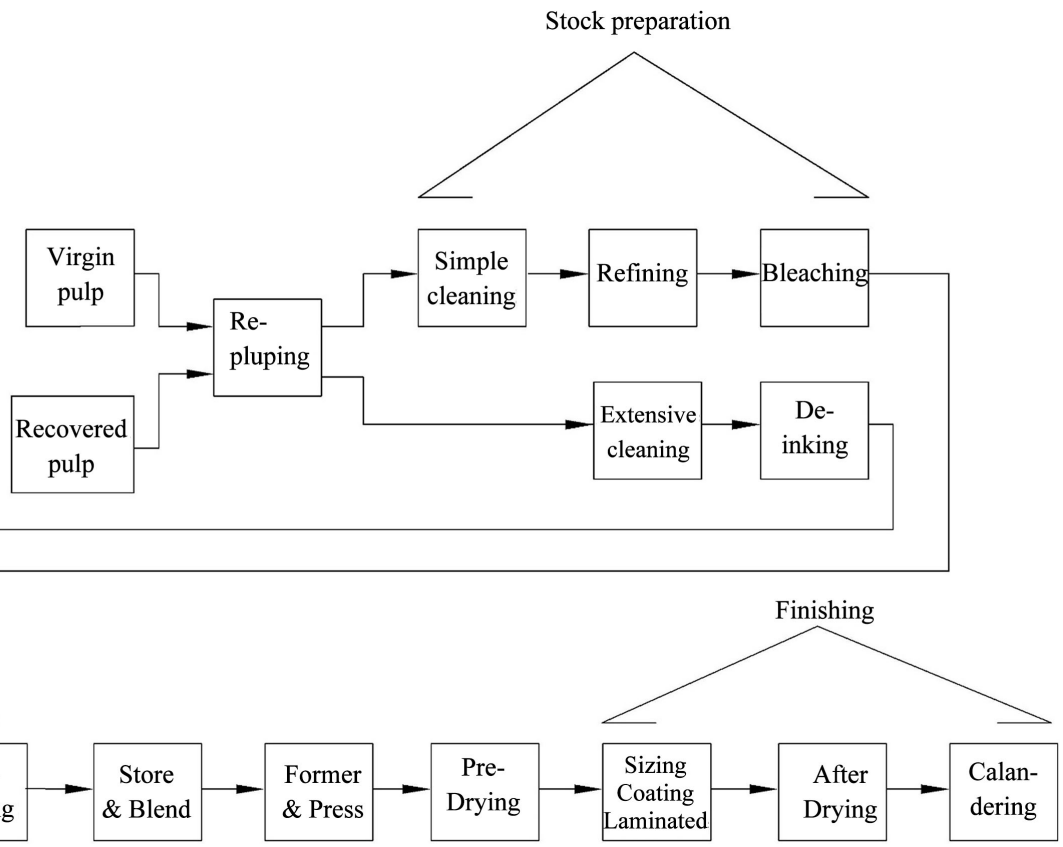

Figure 2. Process flow diagram of paper production. 


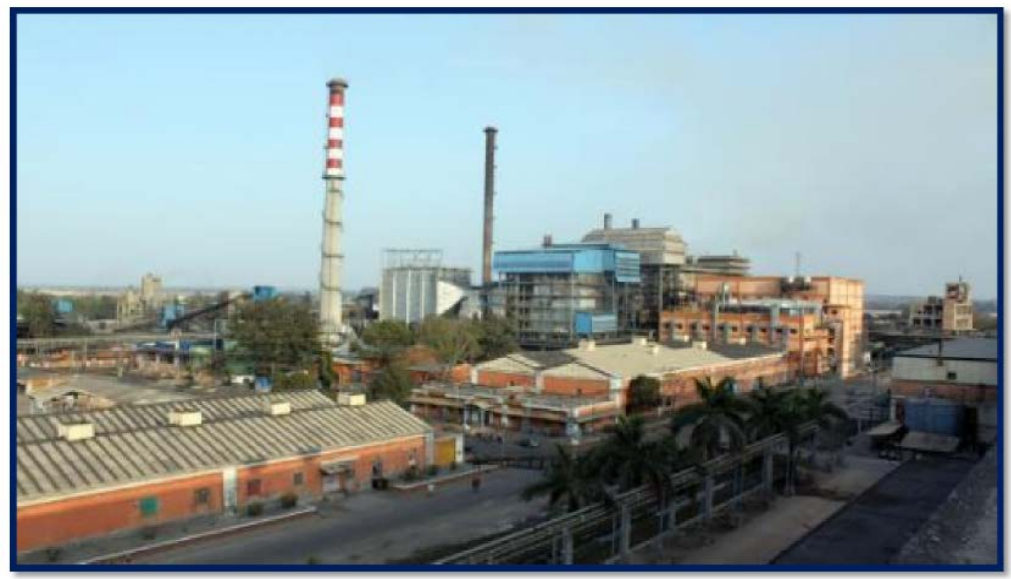

Figure 3. Photograph of the orient paper mills at amlai, shahdol, madhya pradesh, india.

Table 1. Paper production details of various paper machines.

\begin{tabular}{cccccc}
\hline Monthly average & $\begin{array}{c}\text { PM1 } \\
\text { (Tons) }\end{array}$ & $\begin{array}{c}\text { PM2 } \\
\text { (Tons) }\end{array}$ & $\begin{array}{c}\text { PM3 } \\
\text { (Tons) }\end{array}$ & $\begin{array}{c}\text { PM4 } \\
\text { (Tons) }\end{array}$ & $\begin{array}{c}\text { Total } \\
\text { (Tons) }\end{array}$ \\
\hline JAN.-MAR. & 6342 & 1200 & 600 & 450 & 8592 \\
APR.-JUN. & 5842 & 1110 & 540 & 390 & 7882 \\
JUL.-SEP. & 6003 & 1170 & 600 & 360 & 8133 \\
OCT.-DEC. & 5956 & 1260 & 660 & 540 & 8416 \\
\hline
\end{tabular}

Table 2. Thermal and Electrical energy, Consumption of various paper machines.

\begin{tabular}{ccc}
\hline Type of paper machine & $\begin{array}{c}\text { Average electrical } \\
\text { energy consumption } \\
\text { (kWh/ton paper) }\end{array}$ & $\begin{array}{c}\text { Average thermal } \\
\text { energy consumption } \\
(\mathrm{GJ} / \text { ton paper })\end{array}$ \\
\hline PM1 (Writing paper) & 338 & 5.88 \\
PM2 (Tissue paper) & 1107 & 10.40 \\
PM3 (Tissue paper) & 1423 & 11.33 \\
PM4 (Craft paper) & 549 & 8.52 \\
\hline
\end{tabular}

Table 3. Specific energy consumption and Specific $\mathrm{CO}_{2}$ emissions of the plant.

\begin{tabular}{ccccc}
\hline $\begin{array}{c}\text { Yearly quarter } \\
\text { (monthly average) }\end{array}$ & $\begin{array}{c}\text { Coal } \\
\text { consumption } \\
\text { (ton) }\end{array}$ & $\begin{array}{c}\text { Primary energy } \\
\text { used } \\
(\mathrm{GJ})\end{array}$ & $\begin{array}{c}\text { Specific energy } \\
\text { consumption } \\
\text { (GJ/ton of paper) }\end{array}$ & $\begin{array}{c}\text { Specific } \mathrm{CO}_{2} \\
\text { emissions } \\
\text { (tons } \mathrm{CO}_{2} / \text { ton paper) }\end{array}$ \\
\hline Jan.-Mar. & 16,652 & 279,762 & 32.6 & 3.19 \\
Apr.-Jun. & 16,781 & 281,920 & 35.7 & 3.51 \\
Jul.-Sep. & 17,261 & 289,985 & 35.6 & 3.50 \\
Oct.-Dec. & 16,884 & 283,651 & 33.7 & 3.31 \\
\hline
\end{tabular}

\section{Energy Saving Opportunities and Payback Period}

In general, many opportunities exist in a process industry for saving of electrical 
and thermal energies. The pulp \& paper industry also presents opportunities for both types of energy savings. However, the focus of this study was on electrical energy saving, because any saving of electricity (high grade energy) translates into 3 - 4 times saving of primary thermal energy. The electrical energy saving opportunities, which were examined in this study are given below:

\subsection{Replace Mill Water Pump with New Correct Size High Efficiency Pump}

The discharge rate of mill water pump is $1.04 \mathrm{~m}^{3} / \mathrm{s}$; however the requirement of water in the mill is about $0.79 \mathrm{~m}^{3} / \mathrm{s}$. If existing mill water pump (Brake Horse Power 0.01) is replaced by high efficiency pump (Brake Horse Power 0.007), then the electricity reduction potential is about $87 \mathrm{kWh}_{\mathrm{e}}$ as shown below:

Present power consumption per hour $=357 \mathrm{kWh}_{\mathrm{e}}$.

Estimated power requirement for measured parameters per hour $=270 \mathrm{kWh}_{\mathrm{e}}$.

Electricity saving per hour $=87 \mathrm{kWh}_{\mathrm{e}}$.

The plant operation is 24 hours per day for 330 days per year i.e. 7920 hrs per year; the shut-down period for maintenance being 35 days per year.

Hence, annual saving $=(357-270) \mathrm{kWh}_{\mathrm{e}} \times 7920 \mathrm{hrs} . / \mathrm{yr} . \times \mathrm{Rs} 5.00 / \mathrm{kWh}_{\mathrm{e}}=$ Rs 3,445,200.

Approximate saving per year $=$ Rs 3.5 Millions.

Estimated investment $=$ Rs 3.0 Millions.

Simple payback period $=$ Rs 3.0 Millions/Rs 3.5 Millions $\times 12$ months $=10.3$ months.

\subsection{Install Variable Frequency Drive (VFD) for Drinking Water Supply Pump}

As per the water demand which varies during the operation time in the plant, one of the sustainable solutions is to use variable frequency drive pump instead of constant speed drive pump. It may reduce the electricity consumption up to the $6.25 \mathrm{kWh}_{\mathrm{e}}$ as shown below:

At least $30 \%$ energy saving is possible through this measure i.e. $6.25 \mathrm{kWh}_{\mathrm{e}}$ per hour.

Average present power consumption per hour $=20.85 \mathrm{kWh}_{\mathrm{e}}$.

Measured flow $=35 \mathrm{~m}^{3} / \mathrm{hr}$.

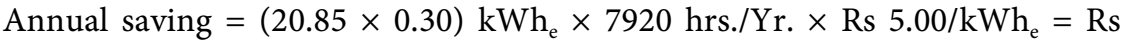
247,698 .

Approximate saving per year = Rs. 0.25 Million.

Estimated investment (for VFD with controls) = Rs 0.18 Million.

Simple payback period $=0.18$ Million/0.25 Million $\times 12$ months $=8.7$ months

\subsection{Replacement of Steam Driven Boiler Feed Pumps by Electric Driven Pump}

In the plant, two boiler feed pumps (i.e. one electric driven \& other steam driven) are currently operated in parallel mode. The power consumption detail of 
both the pumps is listed below:

For this measure, the following data was obtained to find the saving potential:

1) The steam driven boiler feed pump consumes around $275 \mathrm{kWh}_{\mathrm{e}}$ per hour.

2) For the same capacity, the steam driven pump consumes $8 \mathrm{TPH}$ (ton per hour) steam. As recorded, 1 ton per hour of steam can generate $85 \mathrm{kWh}_{\mathrm{e}}$ per hour, hence $8 \mathrm{TPH}$ steam could generate $680 \mathrm{kWh}_{\mathrm{e}}$ electricity per hour.

This means that steam driven boiler feed pump consumes equivalent of 680 $\mathrm{kWh}_{\mathrm{e}}$ per hour as against $275 \mathrm{kWh}_{\mathrm{e}}$ per hour of electric driven pump. So electric driven pump should be installed instead of steam driven pump, as it would save $405 \mathrm{kWh}_{\mathrm{e}}$ per hour.

If the steam driven boiler feed pump is replaced by the electricity driven boiler feed pump in the feed water system, then the electricity reduction potential may be up to $405 \mathrm{kWh}_{\mathrm{e}}$ as shown below:

Hence, annual saving $=405 \mathrm{kWh}_{\mathrm{e}} \times(5.0 \mathrm{Rs} / \mathrm{unit}) \times 7920 \mathrm{hrs}$ per year $=\mathrm{Rs}$ $16,038,000$.

Approximate saving per year $=$ Rs 16 Millions.

Estimated investment for electric driven boiler feed pumps $=$ Rs. 8.0 Millions.

Payback period $=$ Rs 8.0 Millions $/ 16$ Millions $\times 12$ months $=6$ months.

\subsection{Replace Existing Low Efficient Induced Draught (ID) Fans with New High Efficiency ID Fans}

Existing parameters for ID fans in power boilers 1 and 2 (PB1 and PB2) were recorded for operating efficiency and power consumption. The following data was observed:

PB 1-Existing ID fan:

Power consumption: $223.4 \mathrm{kWh}_{\mathrm{e}}$.

Operating Efficiency: $54 \%$.

$>$ PB 2-Existing ID fan.

Power consumption: $208.4 \mathrm{kWh}_{\mathrm{e}}$.

$>$ Operating Efficiency: 55\%.

It is recommended to replace both ID fans in power boiler $1 \& 2$ with high efficiency fans (with at least $70 \%$ efficiency) for the same flow rate $\left(45 \mathrm{~m}^{3} / \mathrm{s}\right.$ ) and discharge pressure. The estimated power consumption for the new ID fans is given below:

PB 1-Proposed new ID fan:

Efficiency: $70 \%$.

Estimated power consumption: $150 \mathrm{kWh}_{\mathrm{e}}$.

PB 2 - Proposed new ID fan.

$>$ Efficiency: $70 \%$.

Estimated power consumption: $130 \mathrm{kWh}_{\mathrm{e}}$.

Annual saving $=\{(223.4+208.4)-(150+130)\} \times 24$ hrs. $\times 330$ days $\times$ Rs $5.0 / \mathrm{kWh}_{\mathrm{e}}=\mathrm{Rs} 6,011,280$.

Approximate saving per year $=$ Rs 6 Millions.

Estimated Investment $=$ Rs 5.0 Millions. 
Simple Payback Period $=$ Rs 5.0 Millions/Rs 6 Millions $\times 12$ months $=10$ months.

\subsection{Electrical Control Rooms Are Provided with Lighting Control Switches at Entry Door for Power Saving}

In the existing 22 electrical control rooms, 10 CFL bulbs (each capacity of $40 \mathrm{~W}$ ) are used in each control room. If lighting control switches are installed at the entry doors that can reduce electricity consumption up to $3 \mathrm{~kW}$.

Annual saving $=3 \mathrm{~kW} \times 24 \mathrm{~h} /$ day $\times 330$ days/yr. $\times$ Rs $5.00 / \mathrm{kWh}_{\mathrm{e}}=\mathrm{Rs} 120,000$.

Approximate saving per year $=$ Rs 0.12 Million.

Estimated Investment $=$ Rs 0.05 Million.

Simple payback period $=$ Rs 0.05 Millions $/$ Rs 0.12 Millions $\times 12$ months $=5.0$ months.

\subsection{High Tension (HT) Capacitor Bank Installed in Chipper House to Improve Power Factor}

The capacity of the existing capacitor bank in the Chipper House is $250 \mathrm{kVA}$ and power factor is 0.67 . If the existing capacitor bank (power factor 0.67) is replaced by the capacitor bank of higher power factor (0.85), it may reduce power loss up to $5 \mathrm{~kW}$.

Present hourly power consumption $=250 \mathrm{kWh}_{\mathrm{e}}$.

Estimated hourly power requirement for measured parameters $=245 \mathrm{kWh}_{\mathrm{e}}$.

Annual saving $=(250-245) \mathrm{kWh}_{\mathrm{e}} \times 7920 \mathrm{hrs} . / \mathrm{yr} . \times \mathrm{Rs} 5.00 / \mathrm{kWh}_{\mathrm{e}}=\mathrm{Rs}_{198,000}$

Approximate saving per year $=$ Rs 0.2 Millions.

Estimated Investment $=$ Rs 0.5 Millions.

Simple payback period $=$ Rs 0.5 Millions/Rs 0.2 Millions $\times 12$ months $=30.0$ months.

\subsection{Utilization of Natural Light by Fixing of Transparent Sheets in Place of Asbestos Sheets}

Quantity $=10$ Nos.

Present hourly power consumption $=700 \mathrm{kWh}_{\mathrm{e}}$.

Estimated hourly power requirement for measured parameters $=680 \mathrm{kWh}_{\mathrm{e}}$. Annual saving $=(700-680) \mathrm{kWh}_{\mathrm{e}} \times 7920 \mathrm{hrs} . / \mathrm{yr} . \times \mathrm{Rs} 5.00 / \mathrm{kWh}_{\mathrm{e}}=\mathrm{Rs}$ 792,000 .

Approximate saving per year $=$ Rs 0.08 Millions.

Estimated Investment $=$ Rs 0.01 Millions.

Simple payback period $=$ Rs 0.01 Millions $/$ Rs 0.08 Millions $\times 12$ months $=1.5$ months.

\subsection{LED Lighting for Bamboo Yards in Place of $400 \mathrm{~W}$ Metal Halide}

In the plant, 21 number of metal halide (each capacity of $400 \mathrm{~W} \& 36,000 \mathrm{lu}$ - 
mens) are currently used in the Bamboo yard. For the same lumens, demand can be met through 21 number of LED bulbs (each capacity of $150 \mathrm{~W}$ ) with lesser power consumption.

Operational running time of metal halide is $12 \mathrm{hrs} /$ day.

Present hourly power consumption $=8.4 \mathrm{kWh}_{\mathrm{e}}$.

Estimated hourly power requirement (due to replacement of LED bulbs) for measured parameters $=2.4 \mathrm{kWh}_{\mathrm{e}}$.

Annual saving $=(8.4-2.4) \mathrm{kWh}_{\mathrm{e}} \times 12 \mathrm{hrs} . /$ day $\times 365$ days $/ \mathrm{yr} . \times \mathrm{Rs}^{5.00 / \mathrm{kWh}_{\mathrm{e}}}$ $=$ Rs 131,400 .

Approximate saving per year $=$ Rs 0.13 Million.

Estimated investment $=$ Rs 0.1 Million.

Simple payback period $=$ Rs 0.1 Million/Rs 0.13 Million $\times 12$ months $=9.2$ months.

\subsection{Reduction of Compressed Air Pressure from 10 to $8.5 \mathrm{Bar}$ (30 kW Motor)-Tissue Paper Machine 1}

As per the estimates of Bureau of Energy Efficiency of the Government of India, 1 bar reductionin the delivery pressure of an air compressor may reduce the power consumption in the range of $6 \%-10 \%$ [10]. It clearly indicates that the reduction in electricity consumption is possible in the Tissue paper machines 1 and 2.

Present hourly power consumption $=28.0 \mathrm{kWh}_{\mathrm{e}}$.

Estimated hourly power requirement for measured parameters $=23.0 \mathrm{kWh}_{\mathrm{e}}$.

Annual saving $=(28.0-23.0) \mathrm{kWh}_{\mathrm{e}} \times 7920$ hrs./yr. $\times \mathrm{Rs} 5.00 / \mathrm{kWh}_{\mathrm{e}}=\mathrm{Rs}$ 198,000.

Approximate saving per year $=$ Rs 0.2 Million.

Estimated investment $=$ Nil (only adjustment of delivery pressure valve is required).

\subsection{Reduction of Compressed Air Pressure from 10 to $8.5 \mathrm{Bar}$ (30kW Motor)-Tissue Paper Machine 2}

Present hourly power consumption $=50.0 \mathrm{kWh}_{\mathrm{e}}$.

Estimated hourly power requirement for measured parameters $=45.0 \mathrm{kWh}_{\mathrm{e}}$.

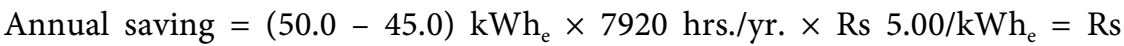
198,000

Approximate saving per year $=$ Rs 0.2 Million.

Estimated investment $=$ Nil (only adjustment of delivery pressure valve is required).

\section{Combined Benefits of Energy Conservation Measures}

Total annual electricity savings from the above listed measures is estimated to be approximately 5.5 million $\mathrm{kWh}_{\mathrm{e}}$. This is equivalent to saving of coal consumption by 3500 tons per year i.e. a reduction in fuel consumption by about $3.5 \%$ as 
well as reduction of carbon emissions by 5775 tons of $\mathrm{CO}_{2}$ per year.

Further, with an estimated purchase cost of coal being Rs. 4000 per ton of coal (Source: Coal purchase cost reported from plant), the monetary benefit of the above measures will be approximately Rs. 14 million per year.

\section{Conclusions and Recommendations}

The average specific energy consumption of a typical paper production unit in India is evaluated as $34.3 \mathrm{GJ} /$ ton paper. It may be noted here that this also includes energy consumption for wood chipping and pulping. The associated specific $\mathrm{CO}_{2}$ emission was evaluated as 3.4 ton $\mathrm{CO}_{2}$ /ton paper. It was further observed that the tissue paper production is much more energy intensive compared to writing and craft paper production.

Several energy conservation opportunities were identified to provide electrical energy savings worth Rs. 14 million per year as well as carbon reduction by about 5800 tons of $\mathrm{CO}_{2}$ per year. Practically all the energy saving measures examined had a payback period of less than two years.

Further energy conservation opportunities and their potential may be explored through the deployment of solar hot water/steam generation systems to meet at least the partial thermal energy requirement of the plant. This will help in further reduce carbon emissions from the plant.

\section{Acknowledgements}

The authors gratefully acknowledge the help and support received from the Orient Paper Mills at Amlai, Shahdol, Madhya Pradesh, India in obtaining the energy use and production data from their plant.

\section{Conflicts of Interest}

The authors declare no conflicts of interest regarding the publication of this paper.

\section{References}

[1] Laurijssen, J., Faaij, A. and Worrell, E. (2013) Benchmarking Energy Use in the Paper Industry: A Benchmarking Study on Process Unit Level. Energy Efficiency, 6, 49-63. https://doi.org/10.1007/s12053-012-9163-9

[2] Kong, L., Price, L., Hasanbeigi, A., Liu, H. and Li, J. (2013) Potenial for Reducing Paper Mill Energy Use and Carbon Dioxide Emissions through Plant-Wide Energy Audits: A Case Study in China. Applied Energy, 102, 1334-1342. https://doi.org/10.1016/j.apenergy.2012.07.013

[3] Saidur, R., Sambandhan, M.T., Hasanuzzaman, M., Devraj, D., Rajkarunakaran, S. and Islam, M.D. (2012) An Energy Flow Analysis in a Paper-Based Industry. Clean Technologies and Environmental Policy, 14, 905-916. https://doi.org/10.1007/s10098-012-0462-9

[4] Barai, M.K. and Saha, B.B. (2015) Energy Security and Sustainability in Japan. Evergreen, 2, 49-56. https://doi.org/10.5109/1500427

[5] Moroga, K., Nagata, A., Kuriyama, Y. and Kobayashi, T. (2015) State of Implemen- 
tation of Environmental and Energy Policies Adopted by the Regional Governments in Japan. Evergreen, 2, 14-23. https://doi.org/10.5109/1544076

[6] Zahara, Z.F. (2018) Economic Assessment of the Sugarcane-Based Biorefinery in Indonesia. Evergreen, 5, 67-77. https://doi.org/10.5109/1936219

[7] Sharma, S.K. (2012) Global Warming and Carbon Footprint: A New Challenge for Indian Chemical Industry. Indian Institute of Chemical Engineers, 54, 36-51. https://doi.org/10.1080/00194506.2012.730685

[8] Dhayaneswaran, Y. and Ashokkumar, L. (2013) A Study on Energy Conservation in Textile Industry. Journal of the Institution of Engineers (India): Series B, 94, 53-60. ttps://doi.org/10.1007/s40031-013-0040-5

[9] Madlool, N.A., Saidur, R., Hossain, M.S. and Rahim, N.A. (2011) A Critical Review on Energy Use and Savings in the Cement Industries. Renewable and Sustainable Energy Reviews, 15, 2042-2060. https://doi.org/10.1016/j.rser.2011.01.005

[10] Bureau of Energy Efficiency, Government of India, Ministry of Power. https://beeindia.gov.in/sites/default/files/3Ch3.pdf 